\title{
Symbolic Consumption of Advertisements for Male Perfumes: Effects of Advertising Appeals and Product Involvement on Advertising Effectiveness
}

\author{
Chao-Ming Yang ${ }^{1} \&$ Chia-Shun Shih ${ }^{2}$ \\ ${ }^{1}$ Department of Visual Communication Design, Ming Chi University of Technolog, New Taipei City, Taiwan \\ ${ }^{2}$ Department of Applied Cosmetolog, Hwa Hsia University of Science and Technolog, New Taipei City, Taiwan \\ Correspondence: Chao-Ming Yang, Department of Visual Communication Design, Ming Chi University of Technolog, \\ 84 Gungjuan Rd., Taishan Dist., New Taipei City 24301, Taiwan. Tel: 886-2908-9899 Ext. 3257.
}

Received: July 23, 2019

Accepted: October 2, 2019

Online Published: November 29, 2019

doi:10.5430/rwe.v10n3p160

URL: https://doi.org/10.5430/rwe.v10n3p160

\begin{abstract}
Because of the trend of metrosexual men, numerous cosmetic brands that originally focused on female customers have extended their product lines to cover the male market, and symbolic consumption in advertisements for male perfumes has flooded society. This study adopted a $3 \times 2$ between-subjects experiment method to examine the effect of two independent variables, namely the appeal of various types of male perfume advertisement (vanity appeal, admiration appeal, and sexual appeal) and the product involvement of consumers (high and low), on attitudes toward the advertisement $\left(\mathrm{A}_{\mathrm{ad}}\right)$, attitudes toward the brand $\left(\mathrm{A}_{\mathrm{b}}\right)$, and purchase intention (PI). This study revealed the following: (1) The types of advertising appeal do affect the $A_{a d}, A_{b}$, and PI of consumers; (2) consumers' product involvement also affects their $A_{a d}, A_{b}$, and PI; (3) vanity appeal and admiration appeal both result in optimal $A_{a d}, A_{b}$, and PI of consumers with high product involvement; and (4) sexual appeal results in optimal $A_{a d}$ and $A_{b}$ for consumers with low product involvement but has no effect on their PI. In today's advertising and marketing business, how a product is made to carry certain symbolic meanings has become particularly crucial; company owners must not overlook the influence of symbolic consumption. This study's results can serve as a reference for company owners and advertisers when planning future advertising and marketing strategies.
\end{abstract}

Keywords: symbolic consumption, male perfumes, advertising appeals, product involvement, advertising effectiveness

\section{Introduction}

The topics of fashion and skin care are no longer exclusively for women. The novel term "metrosexual," which combines metropolis and sexual, refers to the trend of metrosexual men (Pan \& Jamnia, 2015; Bano \& Sharif, 2017). According to the Nielsen survey, only $19 \%$ of men do not follow fashion trends, whereas $56 \%$ of men believe that wearing attractive outfits can improve their confidence; these percentages are only slightly lower than those for women (Kurniawan et al., 2015). Mitchell and Lodhia (2017) indicated that an increasing number of men have started to focus on their tastes and indulgences; therefore, numerous cosmetic brands that originally focused on female customers have extended their product lines to cover the male market. Numerous companies have focused on the metrosexual market. During the past decade, Taiwan's metrosexual market has quietly risen to power in the male consumer market under the influence of Japanese and Korean pop culture. Moreover, the so-called metrosexual market not only includes clothing and accessories but also male perfumes (Wu, 2015; Pan \& Jamnia, 2015). The potential of the metrosexual market is greater than the common imagination.

Male perfume is a sensory product focused on smell and vision. These products are usually pricy and represent certain levels of personalization (Zeng \& Wang, 2016). To appeal to consumers and stimulate purchases, advertisers often employ multiple types of visual stimulation such as celebrity endorsements, brand pursuit, and nudity (Kong, 2016). Detailed observations of the advertisement market in recent years have revealed that advertisers have placed diversified cultural meanings and symbolic values into commercial advertisements for male perfumes. This indicates that the focus of the product that consumers pursue to satisfy their desires has shifted from its function to its external symbolization (Stratton \& Northcote, 2016). This phenomenon of symbolic consumption has quietly spread among 
male perfumes in Taiwan. In fact, in the capitalist social system, consumers usually pay more attention to the symbolic value hiding behind each product, in addition to its format, design, and price (Servidio, 2015).

In Taiwan, making an effective commercial advertisement for male perfume is not easy. According to a survey conducted by Chanel's Taiwan branch, the age group of the main consumers of male perfumes in Taiwan is between 25 and 44 years old. However, approximately half of the male perfume sold is purchased by women or with the presence of a woman, such as a girlfriend or wife (Tseng, 2012). Therefore, advertisements for male perfumes must be designed from the perspective of men and their composition must be established with the minds of women considered to comprehensively achieve effective advertising (Godeo, 2005). With increased emphases on quality of life and interpersonal relationships, perfumes have become a necessity. Relevant advertisements can be seen everywhere (Kong, 2016); one of their prominent characteristics is that they rely heavily on visual effects (Tuna \& Freitas, 2012). However, studies on the advertising and marketing of perfumes are rare in this field. Therefore, the present study determined the symbolic consumption in advertisements for male perfumes. Its main objectives were as follows:

1) To determine the effect of different types of advertising appeal in advertisements for male perfumes on consumers' attitudes toward the advertisement $\left(\mathrm{A}_{\mathrm{ad}}\right)$, attitudes toward the brand $\left(\mathrm{A}_{\mathrm{b}}\right)$, and purchase intention (PI).

2) To determine the effect of product involvement on the $A_{a d}, A_{b}$, and PI of consumers based on advertisements for male perfumes.

3) To determine the effect of interactions between advertising appeals and product involvement on the advertising effectiveness of advertisements for male perfumes.

\section{Theoretical Background}

\subsection{Symbolic Consumption}

Lee (2013) proposed an explicit definition for symbolic consumption: using the act of consumption and the meaning behind it to deliver certain information concerning an individual. The term symbolic consumption first appeared in literature at the beginning of the twentieth century, and was used to explain customers buying a particular product to emphasize the symbolic meaning of their personal identity (Luna-Cortés, 2016). In fact, symbolic consumption has been a popular research topic for scholars over the past 20 years (Ekinci, Sirakaya-Turk, \& Preciado, 2013). Scholars believe that products possess values in use, exchange values, and symbolic values, which are created by marketing and communication tools such as advertisements and packaging (Wattanasuwan, 2005). Additionally, observing consumption activities may reveal characteristics of the consumption culture of a particular region or group, as well as the structure of its social classes (Elliott, 1997).

Specifically, symbolic consumption describes the relationship between a consumer's self and the social culture, as well as the recognition and approval of a self-concept (Ahuvia, 2005; Bhat \& Reddy, 1998; Reed, 2002). From the perspective of marketing today, symbolic consumption involves the consuming concept of products and brands (Dittmar, Beattie, \& Friese, 1996; Ger \& Belk,1996) and is closely related to the social phenomena of consumers proactively creating the self, expressing their past, and demonstrating their current accomplishments and social status (Ekinci et al., 2013; Luna-Cortés, 2016). In addition, under the influences of capitalism and technology media, symbolic consumption in today's society has transformed consumers' consideration of a product from its functionality to its symbolic meanings, or the so-called sociocultural value (Baudrillard, 2005). This value has become the main concern for most consumers in making purchase decisions, as opposed to the functionality of a product (Wattanasuwan, 2005).

In The Consumer Society: Myths and Structures (2016), Baudrillard criticized various problems derived from symbolic consumption from the perspectives of three core concepts, namely sign, simulation, and implosion. Baudrillard indicated that the purchasing of merchandise is the consumption of objects-signs, and that consumption is a manipulated activity of systemized signs. People purchase a product not only for its functionality; the sign that the product carries is also particularly critical. When a product is transformed into a sign through media and assigned a symbolic value, people enter the world of consumption through the guidance of this sign (Baudrillard, 2016). In addition, when basic material demands are met, people will be capable of conspicuous consumption (O'Cass \& McEwen, 2004). Using the symbolic meaning exhibited through merchandise to demonstrate and exhibit one's personal image is an extreme form of symbolic consumption (Charles, Hurst, \& Roussanov, 2009). Based on the abovementioned arguments, this study inferred that the advertising appeals of advertisements for male perfumes will shape the symbolism of said merchandise, and the product involvement of consumers will generate recognition for 
the value of symbolic consumption. These two factors affect the advertising effectiveness of such advertisements. Accordingly, this study proposed the following hypotheses:

1) H1: Different types of advertising appeals in advertisements for male perfumes will affect the $A_{a d}, A_{b}$, and PI of consumers.

2) H2: The level of product involvement in advertisements for male perfumes will affect the $A_{a d}$, $A_{b}$, and PI of consumers.

\subsection{Functionality of Advertising Appeals}

Advertising appeals can be considered the theme of an advertisement, which is not only an embodiment of creativity but also a persuasion strategy adopted by advertisers to provoke consumers (Lee \& Heere, 2018). Kunkel, Walker, and Hodge (2018) indicated that advertisement appeals designed for targeted consumers invoke extraordinary reactions in consumers regarding a particular product, such as drawing attention, interest, or sentimentality. Advertising appeals subtly influence the attitude of consumers toward a particular product or service. Furthermore, advertising appeals can communicate advertisement messages through consumer cognition of a product and their sentimental attachment to a brand (Ruiz \& Silicia, 2004). Advertising appeals can generally be divided into two major categories, namely rational appeals and emotional appeals (Zhang et al., 2014). Perfume advertisements predominantly employ emotional appeals because perfume is related to scents, which often trigger positive emotional responses. Emotional appeals facilitate the triggering of imaginations and emotional responses from consumers (Tuna \& Freitas, 2012).

Today, advertisements for male perfumes also resort to emotional appeals. To enrich the content of an advertisement, designers introduce various emotions into advertisements. On the basis of relevant studies, the present study categorized advertisements featuring such emotions into three types: vanity appeals (Thiyagarajan \& Shanthi, 2012), admiration appeals (Wang et al., 2017), and sexual appeals (Choi et al., 2016). First, vanity is a personality trait that commonly exists in humans. Advertisements focused on brand symbolism usually achieve the objective of vanity appeals. Brand names are valuable consumption symbols because they generate tangible profits and provoke purchasing behaviors in the public toward certain products (Supanvanij \& Amine, 2000). Vanity appeals resort to this recognition of brand symbols to provoke voluntary consumption. Moreover, consumers may be physically and mentally satisfied and exhibit vanity when using products of a particular brand.

Second, the manipulation of admiration appeal is usually linked to the choice of endorser of a product. Advertisers attempt to harness the public's admiration for a celebrity and his or her image to affect the attitudes and behaviors of target consumers (Alsmadi, 2006). Numerous scholars and companies have argued that celebrity endorsement of a product can successfully transfer the positive attitude of consumers' fondness for said celebrity to the product, thereby achieving optimal advertising effectiveness (Goldsmith, Lafferty, \& Newell, 2000; Erdogan, Baker, \& Tagg, 2001). Finally, most scholars have agreed that sexual appeal is a powerful marketing tool, which utilizes ambiguous body language to draw attention and leave impressions on viewers (Black \& Morton, 2017). This appeal exists at the edges of the taboo subject of sex. For this type of advertisement, nudity is the most straightforward means of expression (LaTour \& Henthorne, 1994). Adequate use of sexual appeal can strengthen the effectiveness of advertisement message communication and establish a distinguished brand image. However, its inadequate use will damage product image, provoke complaints, or draw criticism from the public. Therefore, this study inferred that vanity appeals based on brand symbolism and admiration appeals based on celebrity endorsements draw the attention of consumers with a high level of product involvement; whereas the sexual appeal based on body nudity draws the attention of consumers with low level of product involvement. The following hypotheses were then proposed in this study:

3) H3: In advertisements of male perfumes, vanity appeals trigger optimal $A_{a d}, A_{b}$, and PI for consumers with high level of product involvement.

4) H4: In advertisements of male perfumes, admiration appeals trigger optimal $A_{a d}, A_{b}$, and PI for consumers with high level of product involvement.

5) H5: In advertisements of male perfumes, sexual appeals trigger optimal $A_{a d}, A_{b}$, and PI for consumers with low level of product involvement.

\subsection{Effect of Product Involvement}

Zaichkowsky (1986) defined involvement as individuals' level of perception and care for target objects based on personal needs, values, and interests, or the level of interest consumers hold for a product or a service. Studies have referred to involvement as the relevance level between a particular item and an individual (Greenwald \& Leavitt, 
1984; Lastovicka \& Gardner, 1978). Involvement is often used to interpret the purchasing behaviors of consumers; it is regarded as a moderator that affects advertising effectiveness and subtly influences the effectiveness of advertisement message communication (Vakratsas \& Ambler, 1999). Additionally, studies on advertising, marketing, and consumer behavior have focused on the influence of persuasive communication because scholars believe it is the main influencing factor for changes in consumer behavior and attitudes. However, studies on persuasive communication have employed the concept of involvement, which has had a large impact in advertisement and marketing (Zaichkowsky, 1986).

Zaichkowsky (1985) indicated that product involvement refers to the attention consumers pay to a product or a subjective meaning that consumers allocate to it. In other words, product involvement is defined by the cognition of the consumer rather than the product. Andrews, Durvasula, \& Akhter (1990) indicated that product involvement is a continuous link between the product and target of interest set by a consumer. Product involvement represents the level of attention a consumer pays to a product or the meaning and value of a product subjectively allocated by him or her. In fact, involvement is a short-term and unstable state that is subject to interactions between factors such as individuals, products, and scenarios (Kassarajian, 1981). Relevant studies have revealed that individuals' level of involvement is extremely closely related to their intensity of motivation because these two indicators determine the amount of effort consumers will make to satisfy their needs. The higher the involvement and motivation, the more effort consumers will make to satisfy their needs, and thus, pay more attention to relevant information (Dholakia, 2001). In addition, the level of involvement affects the relative importance of various types of products, consumer perception, and levels of fondness for different brands. Therefore, product involvement can refer to the subjective ideas and attention consumers allocate to a product (Bloch \& Richins, 1983).

Beatty and Smith (1987) revealed that consumers with high product involvement are usually goal-oriented and aware of their target merchandise or brand; by contrast, consumers with low product involvement usually develop familiarity with a product through purchases or advertisements and recognize their needs from these processes. In general, consumers with high product involvement are more capable of processing information and will exhibit behaviors such as active research and broad selection (Zaichkowsky, 1986). Brand advertisements for relevant products generate high interest in such consumers and affect their brand evaluation, which creates increasingly frequent product consumption (Laczniak \& Muehling, 1993). This will be the opposite for consumers with low product involvement. In addition, Assael (2001) revealed that consumers with high product involvement proactively research relevant information about a product to make optimal purchasing decisions. Consumers with low product involvement do not seek optimal purchasing decisions; they only wish for a product to be ideal to a certain level, and therefore, they often repeat their previous purchase. The present study inferred that celebrity and fashion symbols related to the endorser in an advertisement for male perfume resonate with consumers with high product involvement; furthermore, advertisements that employ nudity or sex as the main appeal can echo with consumers with low product involvement. Accordingly, the following hypotheses were proposed:

6) H6: Among the three types of advertising appeals for male perfumes, the admiration appeal will trigger optimal $\mathrm{A}_{\mathrm{ad}}, \mathrm{A}_{\mathrm{b}}$, and PI for consumers with a high level of product involvement.

7) H7: Among the three types of advertising appeals for male perfumes, the sexual appeal will trigger optimal $\mathrm{A}_{\mathrm{ad}}$, $\mathrm{A}_{\mathrm{b}}$, and PI for consumers with a low level of product involvement.

\section{Method}

\subsection{Experimental Variables}

First, this study set the advertising appeal of male perfume advertisements as the first independent variable. According to the studies of Thiyagarajan and Shanthi (2012), Wang et al. (2017), and Choi et al. (2016), the emotional appeal in advertisements for male perfumes was further divided into three categories: (1) vanity appeal, which resorts to the brand name as the core appeal to achieve communication and persuasion; (2) admiration appeal, which resorts to celebrity endorsement as the core appeal to achieve communication and persuasion; and (3) sexual appeal, which resorts to nudity as the core appeal to achieve communication and persuasion.

Subsequently, according to Belanchea, Flaviánb, and Pérez-Rueda (2017), the level of product involvement of consumers was set as the second independent variable. Based on the product involvement scale proposed by Youn and Kim (2018), the present study categorized all participants into two groups: high product involvement, which refers to those who pay more attention to messages regarding a product or take initiatives to understand product details; and low product involvement, which refers to those who pay less attention or take fewer initiatives to understand product information.

Finally, studies have revealed that advertisement persuasion is achieved when consumers change their attitudes 
because of the stimulation of advertisement messages (Petty, Fabrigar, \& Wegener, 2003; Boateng \& Okoe, 2015). A consumer's attitude inclination after receiving an advertising message may be used to examine the persuasion effectiveness of the advertisement text (Ang \& Lim, 2006). Accordingly, the dependent variables in this study were as follows: Aad, which refers to the overall reaction of consumers after receiving the advertisement message; Ab, which refers to the overall impression of a brand and product that consumers perceive from the advertisement; and PI, which refers to the possibility of purchasing the product after consumers receive the advertisement message.

\subsection{Questionnaire Design and Pretest}

This study applied a seven-point Likert scale for questionnaire design (from $1=$ strongly disagree to $7=$ strongly agree). Before the formal experiment, 94 respondents were selected using the Internet (men $=40$ and women $=54$ ) to participate in the pretest using an advertisement for Calvin Klein perfume for men. The Cronbach's $\alpha$ test of the pretest data revealed that the internal consistency reliability fell between $\alpha=0.88$ and 0.93 , which was higher than the high reliability standard of 0.7. Details of the pretest are as follows:

1) Questionnaire items for product involvement: I am used to this product; I am interested in information about this product; I think this product is meaningful to me; I think this product fits my needs; I am willing to spend time acquiring relevant information about this product. The internal consistency reliability of this dimension was $\alpha=0.93$.

2) Questionnaire items for $A_{a d}$ : I find this advertisement appealing; I find this advertisement impressive; I find this advertisement intriguing; for me, this is a worthless product advertisement; overall, I like the advertisement design of the product. The internal consistency reliability of this dimension was $\alpha=0.88$.

3) Questionnaire items for $A_{b}$ : I think the brand of this advertisement is good; I think this brand can highlight personal tastes; I think this brand is particularly meaningful; I have a positive impression of the brand in the advertisement; I think this brand is reliable. The internal consistency reliability of this dimension was $\alpha=0.90$.

4) Questionnaire items for PI: I would want to buy the advertised product if I required similar products; I will prioritize this product over other similar products; I think this product is worthy of purchasing; I will recommend my friends to buy this product. The internal consistency reliability of this dimension was $\alpha=0.92$.

\subsection{Experimental Design and Stimuli}

The present study adopted a $3 \times 2$ between-subjects experimental method to operate the two independent variables, namely advertising appeal types (vanity, admiration, and sexual) and consumer product involvement (high and low-involvement). To select a brand of male perfume and endorser fit for the present study, five famous brands (Boss, Bulgari, Chanel, Mont Blanc, and Calvin Klein) and five famous endorsers (Brad Pitt, Robert Pattinson, Ryan Reynolds, David Beckham, and Johnny Depp) were selected for a pretest of advertisement stimuli. The pretest results revealed that the brands with the highest brand awareness in Taiwan were Calvin Klein (34.6\%) and Chanel (33\%), whereas the most popular endorser in Taiwan was David Beckham (45.2\%). Subsequently, three experimental scenarios were developed based on the pretest results (Figures 1-3).
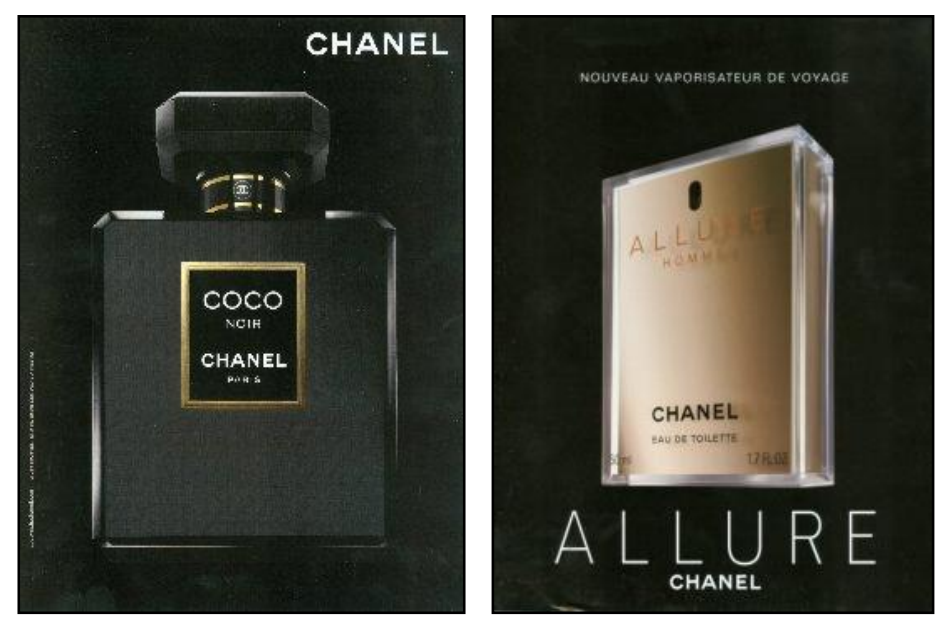

Figure 1. Experimental condition A-vanity appeals with brand name 

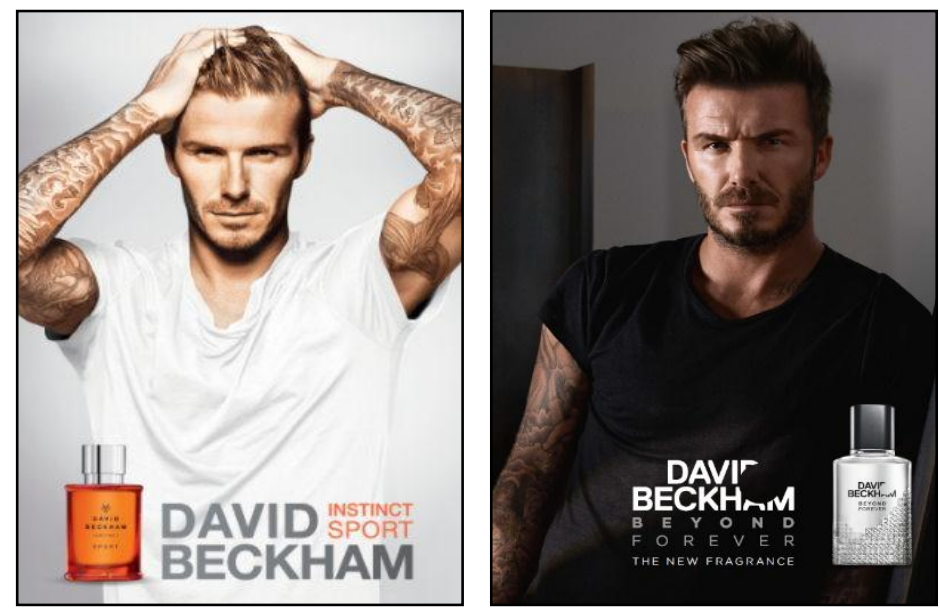

Figure 2. Experimental condition B-admiration appeals with celebrity endorsement
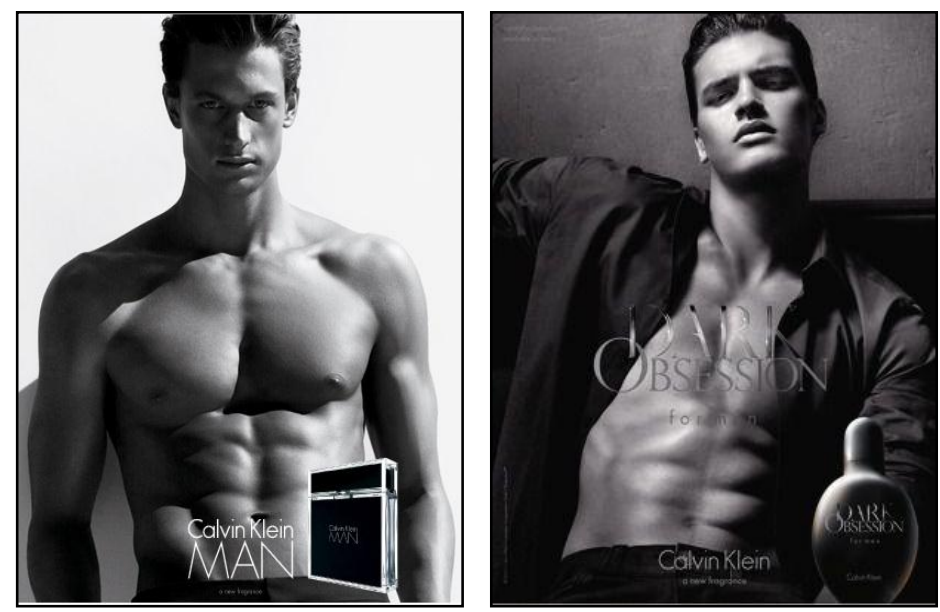

Figure 3. Experimental condition C-sexual appeals with naked body

\subsection{Participants and Experiment}

Purposive sampling was employed to recruit participants through social networking sites. Questionnaires and experimental stimuli were then sent to potential target consumers. To prevent the possibility of repetition in responses, participants were separated into three groups beforehand. In this manner, participants in each group would only receive one experimental scenario and respond to the questionnaire once. The questionnaire survey outline lasted approximately 1 month. For each of the three experimental scenarios, 92 participants were recruited and a total of 276 valid responses were returned $($ men $=152$ and women $=124)$.

\subsection{Distribution of Product Involvement Samples}

Based on relevant studies, a post-hoc clustering method was applied (Meyers-Levy \& Malaviya, 1999; Yang, 2018). The median of the sum of the product involvement scale scores was applied to categorize participants according to their level of product involvement (Haugtvedt, Petty, \& Cacioppo, 1992; Belanche et al., 2017). The distribution results revealed a total of 129 participants with high product involvement $(46.74 \%)$ with Mean $=25.64$ (score range $=20-35)$ and 147 with low product involvement $(53.26 \%)$ with Mean $=12.31$ (score range $=5-19)$. Table 1 presents the detailed distribution of product involvement. 
Table 1. Distribution of product involvement among samples

\begin{tabular}{lccccc}
\hline & & \multicolumn{4}{c}{ Experimental conditions } \\
\cline { 3 - 5 } & & $\begin{array}{c}\text { Condition A } \\
\text { (vanity appeal) }\end{array}$ & $\begin{array}{c}\text { Condition B } \\
\text { (admiration appeal) }\end{array}$ & $\begin{array}{c}\text { Condition C } \\
\text { (sexual appeal) }\end{array}$ & Total \\
\hline Product & high & 40 & 45 & 44 & 129 \\
involvement & low & 49 & 47 & 52 & 147 \\
& Total & 89 & 92 & 96 & 276 \\
\hline
\end{tabular}

Subsequently, these data were input into the statistical analysis software package SPSS. The Cronbach's $\alpha$ test revealed that the internal consistency reliability of participants with high product involvement was $\alpha=0.89$, whereas that of participants with low product involvement was $\alpha=0.87$; the reliability of both sample groups was higher than 0.70 , which indicated a high level of reliability. Consequently, independent sample $t$ tests were adopted to identify differences between the two groups; results revealed that when $t_{(274)}=14.43$, the $p$ value reached the significance level of $p<.01(p=.003)$, and differences were observed between the groups; therefore, this variable was fit to employ as the second independent variable of this study. In addition, Cronbach's $\alpha$ test results for $\mathrm{A}_{\mathrm{ad}}, \mathrm{A}_{\mathrm{b}}$, and PI were $\alpha=0.89, \alpha=0.91$, and $\alpha=0.93$, respectively. The internal consistency reliability of all the three dimensions reached high levels with results higher than 0.70 .

\section{Results}

\subsection{Descriptive Statistics}

According to the statistics on mean values (Table 2), the $\mathrm{A}_{\mathrm{ad}}$ of participants with high product involvement was $M_{\text {high-involvement }}=4.89$ (standard deviation $[S D]=1.12$ ), whereas that of participants with low product involvement was $M_{\text {low-involvement }}=4.63(S D=1.03)$; the $\mathrm{A}_{\mathrm{b}}$ of participants with high product involvement was $M_{\text {high-involvement }}=5.18(S D$ $=1.09)$, whereas that of participants with low product involvement was $M_{\text {low-involvement }}=4.92(S D=0.95)$; and the PI of participants with high product involvement was $M_{\text {high-involvement }}=4.93(S D=1.18)$, whereas that of participants with low product involvement was $M_{\text {low-involvement }}=4.52(S D=1.07)$.

Regarding the advertising appeals, the $\mathrm{A}_{\mathrm{ad}}$ of vanity appeal was $M_{\text {vanity appeal }}=4.33(S D=1.08)$, that of admiration appeal was $M_{\text {admiration appeal }}=5.09(S D=1.01)$, and that of sexual appeal was $M_{\text {sexual appeal }}=4.87(S D=1.02)$. The $\mathrm{A}_{\mathrm{b}}$ of vanity appeal was $M_{\text {vanity appeal }}=4.95(S D=1.02)$, that of admiration appeal was $M_{\text {admiration appeal }}=5.29(S D=0.96)$, and that of sexual appeal was $M_{\text {sexual appeal }}=4.91(S D=1.07)$. Finally, the PI of vanity appeal was $M_{\text {vanity appeal }}=4.58$ $(S D=1.19)$, that of admiration appeal was $M_{\text {admiration appeal }}=4.96(S D=1.08)$, and that of sexual appeal was $M_{\text {sexual }}$ appeal $=4.63(S D=1.12)$.

Table 2. Summary of the M and SD of the independent and dependent variables

\begin{tabular}{llccccccc}
\hline \multirow{2}{*}{ Variables Source } & & \multicolumn{3}{c}{$\mathrm{A}_{\mathrm{ad}}$} & \multicolumn{3}{c}{$\mathrm{A}_{\mathrm{b}}$} & \multicolumn{2}{c}{ PI } \\
\cline { 4 - 9 } & & $n$ & $M$ & $S D$ & $M$ & $S D$ & $M$ & $S D$ \\
\hline Product & high & 129 & 4.89 & 1.12 & 5.18 & 1.09 & 4.93 & 1.18 \\
involvement & low & 147 & 4.63 & 1.03 & 4.92 & 0.95 & 4.52 & 1.07 \\
\hline \multirow{2}{*}{ Advertising } & vanity & 89 & 4.33 & 1.08 & 4.95 & 1.02 & 4.58 & 1.19 \\
appeals & admiration & 96 & 5.09 & 1.01 & 5.29 & 0.96 & 4.96 & 1.08 \\
& sexual & 92 & 4.87 & 1.02 & 4.91 & 1.07 & 4.63 & 1.12 \\
\hline
\end{tabular}

Note: $\mathrm{A}_{\mathrm{ad}}=$ attitudes toward advertisement; $\mathrm{A}_{\mathrm{b}}=$ attitudes toward brand; $\mathrm{PI}=$ purchase intention

\subsection{Effect of the Independent Variables on the Dependent Variables}

An independent sample $t$ test was conducted to examine the effect of product involvement on $A_{a d}, A_{b}$, and PI. The results revealed that the effect of product involvement on $\mathrm{A}_{\mathrm{ad}}$ was significant; when $t_{(274)}=2.02, p=.044$, which reached the significance level of $p<.05\left(M_{\text {low-involvement }}=4.89\right.$ and $\left.M_{\text {high-involvement }}=4.63\right)$. The effect of product involvement on $\mathrm{A}_{\mathrm{b}}$ was significant; when $t_{(274)}=2.12, p=.035$, which reached the significance level of $p<.05$ $\left(M_{\text {low-involvement }}=5.18\right.$ and $\left.M_{\text {high-involvement }}=4.92\right)$. Regarding the effect of product involvement on PI, the results 
revealed that when $t_{(274)}=3.04, p=.003$, which reached the significance level of $p<.01\left(M_{\text {low-involvement }}=4.93\right.$ and $M_{\text {high-involvement }}=4.52$ ).

Next, a one-way analysis of variance (ANOVA) was used to test the effect of advertising appeal types on $\mathrm{A}_{\mathrm{ad}}, \mathrm{A}_{\mathrm{b}}$, and PI. The results revealed that the effect of advertising appeals on $\mathrm{A}_{\text {ad }}$ was significant; when $F_{(2,274)}=13.34, p$ $=.000$, which reached the significance level of $p<.001\left(M_{\text {admiration appeal }}=5.09, M_{\text {sexual appeal }}=4.87\right.$, and $M_{\text {vanity appeal }}=$ 4.33). With respect to $\mathrm{A}_{\mathrm{b}}$, when $F_{(2,274)}=3.82, p=.023$, which reached the significance level of $p<.05\left(M_{\text {admiration }}\right.$ appeal $=5.29, M_{\text {vanity appeal }}=4.95$, and $\left.M_{\text {sexual appeal }}=4.91\right)$. The effect of advertising appeals on PI was significant; when $F_{(2,274)}=3.14, p=.045$, which reached the significance level of $p<.05\left(M_{\text {admiration appeal }}=4.96, M_{\text {sexual appeal }}=4.63\right.$, and $\left.M_{\text {vanity appeal }}=4.58\right)$.

The abovementioned results revealed that product involvement and advertising appeals caused different levels of effects on $\mathrm{A}_{\mathrm{ad}}, \mathrm{A}_{\mathrm{b}}$, and PI. Subsequently, a two-way ANOVA test revealed that the $F$ value, which represents the interaction between the two independent variables on the dependent variables (product involvement $\times$ advertising appeals), reached the significance level of $p<.001\left(\mathrm{~A}_{\mathrm{ad}}: p=.000, \mathrm{~A}_{\mathrm{b}}: p=.000\right.$, and PI: $\left.p=.000\right)$. These experiment results revealed that the $A_{a d}, A_{b}$, and PI of the participants were affected by the interaction of the two independent variables (Table 3 ).

Consequently, this study analyzed the simple main effect and conducted a post-hoc test using the Tukey's honest significant difference (HSD) test. The results of these tests were as follows (Table 4):

1) Product involvement: For participants with high product involvement, advertisements adopting the admiration appeal triggered optimal $\mathrm{A}_{\mathrm{ad}}\left(F_{(2,127)}=5.91, p<.01\right), \mathrm{A}_{\mathrm{b}}\left(F_{(2,127)}=9.38, p<.001\right)$, and $\mathrm{PI}\left(F_{(2,127)}=7.20, p\right.$ $<.01)$. For participants with low product involvement, advertisements adopting the sexual appeal triggered optimal $\mathrm{A}_{\mathrm{ad}}\left(F_{(2,145)}=22.87, p<.001\right), \mathrm{A}_{\mathrm{b}}\left(F_{(2,145)}=5.02, p<.05\right.$, and $\mathrm{PI}\left(F_{(2,145)}=4.21, p<.05\right)$.

2) Advertising appeals: The vanity appeal triggered optimal $\mathrm{A}_{\mathrm{ad}}\left(F_{(1,88)}=14.21, p<.001\right), \mathrm{A}_{\mathrm{b}}\left(F_{(1,88)}=15.40, p\right.$ $<.001$, and PI $\left(F_{(1,88)}=12.11, p<.01\right)$ for participants with high product involvement. The admiration appeal also triggered optimal $\mathrm{A}_{\mathrm{ad}}\left(F_{(1,95)}=5.28, p<.05\right), \mathrm{A}_{\mathrm{b}}\left(F_{(1,95)}=6.50, p<.05\right)$, and PI $\left(F_{(1,95)}=12.48, p<.001\right)$ for participants with high product involvement. Finally, the sexual appeal triggered optimal $\mathrm{A}_{\text {ad }}\left(F_{(1,91)}=7.47, p\right.$ $<.01), \mathrm{A}_{\mathrm{b}}\left(F_{(1,91)}=5.18, p<.05\right)$, and PI $\left(F_{(1,91)}=2.31, p>.05\right)$ for participants with low product involvement.

Table 3. The effects of product involvement and advertising appeals on $\mathrm{A}_{\mathrm{ad}}, \mathrm{A}_{\mathrm{b}}$, and PI

\begin{tabular}{|c|c|c|c|c|c|}
\hline Variables Source & $S S$ & $d f$ & $M S$ & $F$ & Sig. \\
\hline $\begin{array}{l}\mathbf{A}_{\text {ad }} \\
\text { Product involvement (A) } \\
\text { Advertising appeals (B) } \\
\mathrm{A} \times \mathrm{B}\end{array}$ & $\begin{array}{r}3.85 \\
26.50 \\
23.11 \\
\end{array}$ & $\begin{array}{l}1 \\
2 \\
2 \\
\end{array}$ & $\begin{array}{r}3.85 \\
13.25 \\
11.56 \\
\end{array}$ & $\begin{array}{r}3.89 \\
13.41 \\
11.69 \\
\end{array}$ & $\begin{array}{l}.050^{*} \\
.000^{* * *} \\
.000^{* * *}\end{array}$ \\
\hline $\begin{array}{l}\mathbf{A}_{\mathbf{b}} \\
\text { Product involvement (A) } \\
\text { Advertising appeals (B) } \\
\mathrm{A} \times \mathrm{B}\end{array}$ & $\begin{array}{r}4.56 \\
6.93 \\
20.43 \\
\end{array}$ & $\begin{array}{l}1 \\
2 \\
2 \\
\end{array}$ & $\begin{array}{r}4.56 \\
3.47 \\
10.22 \\
\end{array}$ & $\begin{array}{r}4.81 \\
3.66 \\
10.78 \\
\end{array}$ & $\begin{array}{l}.029^{*} \\
.027^{*} \\
.000^{* * * *}\end{array}$ \\
\hline $\begin{array}{l}\text { PI } \\
\text { Product involvement (A) } \\
\text { Advertising appeals (B) } \\
\mathrm{A} \times \mathrm{B}\end{array}$ & $\begin{array}{r}11.30 \\
6.91 \\
19.90\end{array}$ & $\begin{array}{l}1 \\
2 \\
2\end{array}$ & $\begin{array}{r}11.30 \\
3.46 \\
9.95\end{array}$ & $\begin{array}{l}9.55 \\
2.92 \\
8.41\end{array}$ & $\begin{array}{l}.002^{* * *} \\
.056 \\
.006^{* * * *}\end{array}$ \\
\hline
\end{tabular}

Note: $\mathrm{A}_{\mathrm{ad}}=$ attitudes toward advertisement; $\mathrm{A}_{\mathrm{b}}=$ attitudes toward brand; $\mathrm{PI}=$ purchase intention

p $<.05 ;{ }^{* *} \mathrm{p}<.01 ;{ }^{* * *} \mathrm{p}<.001$ 
Table 4. Results of the simple main effect analysis and Tukey's HSD test

\begin{tabular}{|c|c|c|c|c|c|c|}
\hline Variables Source & $S S$ & $d f$ & $M S$ & $\boldsymbol{F}$ & Sig. & Post-hoc \\
\hline \multicolumn{7}{|l|}{$\mathbf{\mathbf { A } _ { \mathrm { ad } }}$} \\
\hline \multicolumn{7}{|l|}{ Product involvement (A) } \\
\hline in vanity appeal (B1) & 14.59 & 1 & 14.59 & 14.21 & $.000^{* * *}$ & A $1>$ A 2 \\
\hline in admiration appeal (B2) & 5.13 & 1 & 5.13 & 5.28 & $.024^{*}$ & A $1>$ A 2 \\
\hline in sexual appeal (B3) & 7.23 & 1 & 7.23 & 7.47 & $.008^{* *}$ & $\mathrm{~A} 2>\mathrm{A} 1$ \\
\hline \multicolumn{7}{|l|}{ Advertising appeals (B) } \\
\hline in high-involvement (A1) & 13.78 & 2 & 6.89 & 5.91 & $.003^{* *}$ & $\mathrm{~B} 2>\mathrm{B} 1 ; \mathrm{B} 3>\mathrm{B} 1$ \\
\hline in low-involvement (A2) & 37.12 & 2 & 18.56 & 22.87 & $.000^{* * *}$ & $\mathrm{~B} 3>\mathrm{B} 2 ; \mathrm{B} 2>\mathrm{B} 1$ \\
\hline \multicolumn{7}{|l|}{$\mathbf{A}_{\mathrm{b}}$} \\
\hline \multicolumn{7}{|l|}{ Product involvement (A) } \\
\hline in vanity appeal (B1) & 13.74 & 1 & 13.74 & 15.40 & $.000^{* * *}$ & $\mathrm{~A} 1>\mathrm{A} 2$ \\
\hline in admiration appeal (B2) & 5.59 & 1 & 5.59 & 6.50 & $.012^{*}$ & A $1>$ A 2 \\
\hline in sexual appeal (B3) & 5.65 & 1 & 5.65 & 5.18 & $.025^{*}$ & $\mathrm{~A} 2>\mathrm{A} 1$ \\
\hline \multicolumn{7}{|l|}{ Advertising appeals (B) } \\
\hline in high-involvement (A1) & 19.68 & 2 & 9.84 & 9.38 & $.000^{* * *}$ & $\mathrm{~B} 2>\mathrm{B} 1 ; \mathrm{B} 1>\mathrm{B} 3$ \\
\hline in low-involvement (A2) & 8.49 & 2 & 4.25 & 5.02 & $.008^{* *}$ & $\mathrm{~B} 3>\mathrm{B} 2 ; \mathrm{B} 2>\mathrm{B} 1$ \\
\hline \multicolumn{7}{|l|}{ IP } \\
\hline \multicolumn{7}{|l|}{ Product involvement (A) } \\
\hline in vanity appeal (B1) & 15.32 & 1 & 15.32 & 12.11 & $.001^{* *}$ & $\mathrm{~A} 1>\mathrm{A} 2$ \\
\hline in admiration appeal (B2) & 13.00 & 1 & 13.00 & 12.48 & $.001^{* *}$ & $\mathrm{~A} 1>\mathrm{A} 2$ \\
\hline in sexual appeal (B3) & 2.88 & 1 & 2.88 & 2.31 & .132 & - \\
\hline \multicolumn{7}{|l|}{ Advertising appeals (B) } \\
\hline in high-involvement (A1) & 18.48 & 2 & 9.14 & 7.20 & $.001^{* *}$ & $\mathrm{~B} 2>\mathrm{B} 1 ; \mathrm{B} 1>\mathrm{B} 3$ \\
\hline in low-involvement (A2) & 9.12 & 2 & 4.56 & 4.21 & $.017^{*}$ & $\mathrm{~B} 3>\mathrm{B} 2 ; \mathrm{B} 2>\mathrm{B} 1$ \\
\hline
\end{tabular}

Note: $\mathrm{A}_{\mathrm{ad}}=$ attitudes toward advertisement; $\mathrm{A}_{\mathrm{b}}=$ attitudes toward brand; $\mathrm{PI}=$ purchase intention

${ }^{*} \mathrm{p}<.05 ;{ }^{* *} \mathrm{p}<.01 ;{ }^{* * *} \mathrm{p}<.001$

\section{Discussion}

\subsection{Effect of Advertising Appeals in Symbolic Consumption of Advertisement}

The results obtained in this study revealed that the factor of advertising appeals does affect the $A_{a d}, A_{b}$, and PI of the audience of male perfume advertisements; thus, $\mathrm{H} 1$ was valid. Additionally, this study revealed that of all three emotional appeals, advertisements adopting the admiration appeal resulted in the optimal advertising effectiveness.

In modern society, symbolic consumption is a form of approval of self-value and a means for individuals to connect with the society and life to which they belong (Wattanasuwan, 2005). In advertisements adopting the admiration appeal, advertisers use the social symbolism of celebrities to prompt the audience to conduct the symbolic consumption of celebrities. This type of admiration for celebrities and pursuit of pop culture seem to imply certain creations of self-concept and self-identification (Sirgy, 1982). In today's consumerist society, purchasing a particular brand conveys the prestige and social status of an individual (O'Cass \& McEwen, 2004). Responding to advertisements with celebrity endorsers by purchasing the product highlights the knowledge and credibility of an individual regarding the product (Silvera \& Austad, 2003). In fact, both purchasing behaviors are considered conspicuous consumption behaviors (Rucker \& Galinsky, 2009). This study revealed that advertisements for male perfumes adopting the admiration appeal obtained optimal Aad, Ab, and PI. Therefore, advertisers may use this result as a reference to establish precise advertising appeal strategies based on symbolic consumption.

\subsection{Effect of Product Involvement in Symbolic Consumption of Advertisement}

The results revealed that product involvement does affect the $A_{a d}, A_{b}$, and PI of the audience of male perfume advertisements; thus, $\mathrm{H} 2$ was valid. In addition, participants with high product involvement exhibited greater $\mathrm{A}_{\mathrm{ad}}, \mathrm{A}_{\mathrm{b}}$, and PI than did those with low product involvement. These results revealed that male perfumes are closely related to individuality. Therefore, the appearances and messages in advertisement texts have great impacts on the attitudes and inclination of consumers with high product involvement.

The literature review revealed that consumers with high product involvement are usually more capable of processing information and taking initiatives to research relevant products and brands. These consumers pay great attention to 
products and are aware of their own preferences. Therefore, compared with consumers with low product involvement, consumers with high product involvement are more comprehensive and precise in product selection as well as more motivated to process the information of a product or brand, which subtly helps their decision-making or evaluations and generates purchasing intention. Therefore, advertisement exposure channels that fit the receiving habits of consumers with high product involvement can increase the possibility of consumption (Petty, Cacioppo, \& Schumann, 1983). On this basis, analysis of the advertisement samples in this experiment was conducted, revealing that advertisements adopting the vanity and admiration appeals clearly demonstrated the brand and celebrity endorsers in the advertisement, enabling consumers with high product involvement to think about brand information following the central route (Petty \& Cacioppo, 1983). Once consumers with high product involvement determine brand information to fit their personal expectations, their attitudes and inclination will be superior to those of consumers with low product involvement.

\subsection{Interactive Effects Between the Advertising Appeals and Product Involvement}

The analysis of this effect revealed that advertisements adopting the vanity and admiration appeals triggered optimal $A_{a d}, A_{b}$, and PI for consumers with high product involvement; by contrast, the sexual appeal triggered optimal $A_{a d}$ and $A_{b}$ for consumers with low product involvement, yet demonstrated no significant effect on PI. In other words, the $\mathrm{H} 3$ and $\mathrm{H} 4$ were valid, but $\mathrm{H} 5$ was only partially valid. In addition, consumers with high product involvement might exhibit optimal $\mathrm{A}_{\mathrm{ad}}, \mathrm{A}_{\mathrm{b}}$, and PI when viewing advertisements adopting the admiration appeal; by contrast, consumers with low product involvement might exhibit optimal $\mathrm{A}_{\mathrm{ad}}, \mathrm{A}_{\mathrm{b}}$, and PI in the face of advertisements adopting the sexual appeal. Therefore, $\mathrm{H} 6$ and $\mathrm{H} 7$ were valid.

According to the abovementioned results, this study made inferences based on the characteristics of consumers with high product involvement. Such consumers are often extremely sensitive to messages about a product in advertisement texts. They not only take initiatives to research information related to the product and learn about attributes of different brands and products, but also react to messages and make purchasing decisions based on past experiences and existing knowledge (Petty \& Cacioppo, 1983). Therefore, consumers with high product involvement refine messages for evaluation and processing. Advertisements adopting the vanity appeal (emphasizing brand names) and admiration appeal (emphasizing celebrity endorsements) fit the message-processing model of consumers with high product involvement. Consumers with high product involvement can clearly learn about a brand, product, and endorser from this type of advertisement and reflect more positive attitudes compared with consumers with low product involvement. Although further studies are required to determine whether such positive attitudes can effectively establish brand loyalty, the results of this study revealed that adding symbolic consumption values to merchandise enables advertisers to touch the inner desire of consumers with high product involvement to consume.

Additionally, purchase decision-making and message judgements of consumers with low product involvement can be used to determine the effect of sexual appeal on these consumers. Because they seldom pay attention to male perfumes, they possess little understanding of and information on brands or endorsers. Therefore, advertisements focusing on the brand or its endorser are unlikely to draw their attention or provoke them to conduct in-depth processing of such advertisement messages (Zaichkowsky, 1986). However, the peripheral route (Petty \& Cacioppo, 1983) that is unrelated to substantial product information, such as the humor, outfit of the endorser, or nudity of the model, will provoke the interest and curiosity of consumers with low product involvement. This analysis should be able to further explain why advertisements for male perfume that adopted sexual appeal triggered more positive Aad and $\mathrm{Ab}$ for consumers with low product involvement. However, according to this study, the peripheral route approach does not effectively stimulate the PI of consumers with low product involvement. These results indicated that consumers with low product involvement are clearly more cautious when evaluating a purchase of symbolic consumption.

\section{Conclusions}

First, the pretest of the experiment stimuli revealed enormous differences in the knowledge of perfume brands and endorsers for consumers with different levels of product involvement. Consumers with high product involvement know all relevant information regarding a product and are considerably aware of the brands and endorsers they prefer. In addition, theses consumers possess much more comprehensive concepts about print advertisements for male perfumes; therefore, their choices are less likely to be influenced by others. The results of the official questionnaire proved that the advertising effectiveness of print advertisements for male perfumes is more effective for consumers with high product involvement than those with low product involvement. By contrast, consumers with low product involvement were complete strangers to the five perfume brands and endorsers in the experiment pretest. These consumers were only able to relate to the questionnaire items by piecing together memories or being helped by 
others. The results of the experiment revealed that consumers with low product involvement exhibited inferior $\mathrm{A}_{\mathrm{ad}}$ and $A_{b}$ compared with consumers with high product involvement; moreover, the PI of consumers with low product involvement was mitigated. Therefore, advertisers are advised to learn the differences in advertising effectiveness for consumers with different levels of product involvement before launching print advertisements for male perfumes. Advertisement communication and persuasion can be achieved through designing print advertisements for perfumes that fit the taste of the market, employing market segmentation based on advertising media or online platforms.

Second, the variables of advertising appeals and product involvement interacted with each other. Based on the level of a consumers' product involvement, their attitudes differed in response to different advertising appeals. The experiment results revealed that consumers with high product involvement responded best to advertisements that adopted admiration appeal, followed by vanity appeal and sexual appeal. For consumers with low product involvement, advertisements adopting sexual appeal resulted in optimal advertising effectiveness, followed by admiration appeal and vanity appeal. These results are not only related to the level of product involvement of consumers but also their state of mind. In fact, consumers with high product involvement are often compelled by rational buying motives; therefore, advertisements containing product information they care about are particularly persuasive. By contrast, consumers with low product involvement are often compelled by the buying motive of emulation, and are easily attracted to scenarios or images in an advertisement; therefore, advertisements adopting sexual appeal are particularly effective for them. In sum, advertisers must design their advertising appeals for male perfumes in accordance with consumers' product involvement level. This can optimize the advertising effectiveness.

Finally, advertisers must consider methods to enable consumers with different levels of product involvement to receive direct or indirect advertisement messages, as well as to imperceptibly improve advertisement values to obtain optimal advertising effectiveness. On the basis of the research results, advertisers are advised to consider and assess the lifestyles and purchasing habits of consumers with high and low product involvement to select appropriate media and platforms for advertisement exposure. Consumers of male perfumes with high product involvement have a considerable understanding of the products and take initiatives to collect relevant information; therefore, advertisers can place advertisements that adopt admiration appeal on platforms such consumers frequently visit, such as fashion magazines, online shopping websites, and perfume websites. By contrast, consumers with low product involvement have little understanding of the products and take no initiatives to collect relevant information; advertisers are advised to make extra effort and invest more thought into placing advertisements that adopt sexual appeal somewhere consumers with low product involvement are likely to see them, such as lightbox advertisements in MRT stations, advertisements in MRT trains, and billboards. These approaches will force such consumers to be stimulated by advertisements and pay attention to them, with the intention of driving them to make trial purchases that may lead to the establishment of long-term brand loyalty.

\section{Acknowledgement}

The author gratefully acknowledges the support for this research provided by the Ministry of Science and Technology of Taiwan under Grants No. MOST-107-2410-H-131-001.

\section{References}

Ahuvia, A. C. (2005). Beyond the extended self: Loved objects and consumers' identity narratives. Journal of Consumer Research, 32(1), 171-184. https://doi.org/10.1086/429607

Alsmadi, S. (2006). The power of celebrity endorsement in brand choice behavior: An empirical study of consumer attitudes. Journal of Accounting, Business \& Management, 13, 69-84.

Andrews, J. C., Durvasula, S., \& Akhter, S. H. (1990). A framework for conceptualizing and measuring the involvement construct in advertising research. Journal of Advertising, 19(4), 27-40. https://doi.org/10.1080/00913367.1990.10673198

Ang, S. H., \& Lim, E. A. C. (2006). The influence of metaphors and product type on brand personality perceptions and attitudes. Journal of Advertising, 35(2), 39-53. https://doi.org/10.1080/00913367.2006.10639226

Assael, H. (2001). Consumer Behaviour and Marketing Action (6th ed.). New York: Thompson.

Bano, S., \& Sharif, M. A. M. (2017). Origins of metrosexual: In the light of events. Global Business and Management Research, 9(1s), 605-612.

Baudrillard, J. (2005). The System of Objects. London: Verso.

Baudrillard, J. (2016). The Consumer Society: Myths and Structures. London: Sage. https://doi.org/10.4135/9781526401502 
Beatty, S. E., \& Smith, S. M. (1987). External search effort: an investigation across several product categories. Journal of Consumer Research, 14(1), 83-95. https://doi.org/10.1086/209095

Belanche, D., Flavián, C., \& Pérez-Rueda, A. (2017). Understanding interactive online advertising: Congruence and product involvement in highly and lowly arousing, skippable video ads. Journal of Interactive Marketing, 37, 75-88. https://doi.org/10.1016/j.intmar.2016.06.004

Bhat, S., \& Reddy, S. K. (1998). Symbolic and functional positioning of brands. Journal of Consumer Marketing, 15(1), 32-43. https://doi.org/10.1108/07363769810202664

Black, I. R., \& Morton, P. (2017). Appealing to men and women using sexual appeals in advertising: In the battle of the sexes, is a truce possible?. Journal of Marketing Communications, 23(4), 331-350. https://doi.org/10.1080/13527266.2015.1015108

Bloch, P. H., \& Richins, M. L., (1983). A theoretical model for the study of product importance perceptions. Journal of Consumer Research, 47(2), 69-81. https://doi.org/10.2307/1251198

Boateng, H., \& Okoe, A. F. (2015). Consumers' attitude towards social media advertising and their behavioural response: The moderating role of corporate reputation. Journal of Research in Interactive Marketing, 9(4), 299-312. https://doi.org/10.1108/JRIM-01-2015-0012

Charles, K. K., Hurst, E., \& Roussanov, N. (2009). Conspicuous consumption and race. The Quarterly Journal of Economics, 124(2), 425-467. https://doi.org/10.1162/qjec.2009.124.2.425

Choi, H., Yoo, K., Reichert, T., \& LaTour, M. S. (2016). Do feminists still respond negatively to female nudity in advertising? Investigating the influence of feminist attitudes on reactions to sexual appeals. International Journal of Advertising, 35(5), 823-845. https://doi.org/10.1080/02650487.2016.1151851

De Gregorio Godeo, E. (2005, May). Male-perfume advertising in male magazines and visual discourse in contemporary Britain: A social semiotics approach. Image [\&] Narrative. Online Magazine of the Visual Narrative, $11 . \quad$ Retrieved 1 July 2019, from http://www.imageandnarrative.be/worldmusicb_advertising/godeo.htm

Dholakia, U. M. (2001). A motivational process model of product involvement and consumer risk perception. European Journal of Marketing, 35(11/12), 1340-1362. https://doi.org/10.1108/EUM0000000006479

Dittmar, H., Beattie, J., \& Friese, S. (1996). Objects, decision considerations and self-image in men's and women's impulse purchases. Acta Psychologica, 93(1-3), 187-206. https://doi.org/10.1016/0001-6918(96)00019-4

Ekinci, Y., Sirakaya-Turk, E., \& Preciado, S. (2013). Symbolic consumption of tourism destination brands. Journal of Business Research, 66(6), 711-718. https://doi.org/10.1016/j.jbusres.2011.09.008

Elliott, R. (1997). Existential consumption and irrational desire. European Journal of Marketing, 31(3/4), 285-296. https://doi.org/10.1108/03090569710162371

Erdogan, B. Z., Baker, M. J., \& Tagg, S. (2001). Selecting celebrity endorsers: The practitioner's perspective. Journal of Advertising Research, 41(3), 39-48. https://doi.org/10.2501/JAR-41-3-39-48

Ger, G., \& Belk, R. W. (1996). Cross-cultural differences in materialism. Journal of Economic Psychology, 17(1), 55-77. https://doi.org/ 10.1016/0167-4870(95)00035-6

Goldsmith, R. E., Lafferty, B. A., \& Newell, S. J. (2000). The impact of corporate credibility and celebrity credibility on consumer reaction to advertisements and brands. Journal of Advertising, 29(3), 43-54. https://doi.org/10.1080/00913367.2000.10673616

Greenwald, A. G., \& Leavitt, C. (1984). Audience involvement in advertising: Four levels. Journal of Consumer Research, 11(1), 581-592. https://doi.org/10.1086/208994

Haugtvedt, C. P., Petty, R. E., \& Cacioppo, J. T. (1992). Need for cognition and advertising: Understanding the role of personality variables in consumer behavior. Journal of Consumer Psychology, 1(3), 239-260. https://doi.org/10.1016/S1057-7408(08)80038-1

Kassarjian, H. H. (1981). Low involvement: A second look. Advances in Consumer Research, 8(1), 31-34.

Kong, R. (2016). On Perfume Advertisement in Film Art during the Digital Age. Proceedings of the 2016 International Conference on Arts Design and Contemporary Education, 873-875. Atlantis Press. https://doi.org/10.2991/icadce-16.2016.212 
Kunkel, T., Walker, M., \& Hodge, C. M. (2018). The influence of advertising appeals on consumer perceptions of athlete endorser brand image. European Sport Management Quarterly, 1-23. https://doi.org/10.1080/16184742.2018.1530688

Kurniawan, A. W., Listian, S. S., Nurhadi, Z. F., \& Hendrawan, H. (2018). Metrosexual Lifestyle and Interpersonal Relationships. Proceedings of the International Conference on Media and Communication Studies (ICOMACS 2018). Atlantis Press. https://doi.org/10.2991/icomacs-18.2018.5

Laczniak, R. N., \& Muehling, D. D. (1993). Toward a better understanding of the role of advertising message involvement in ad processing. Psychology and Marketing, 10(4), 301-319. https://doi.org/10.1002/mar.4220100405

LaTour, M. S., \& Henthorne, T. L. (1994). Ethical judgments of sexual appeals in print advertising. Journal of advertising, 23(3), 81-90. https://doi.org/10.1080/00913367.1994.10673453

Lastovicka, J. L., \& Gardner, D. M. (1978). Low involvement versus high involvement cognitive structures. Advances in Consumer Research, 5(1), 87-92.

Lee, E. J. (2013). A prototype of multicomponent brand personality structure: A consumption synmbolism approach. Psychology \& Marketing, 30(2), 173-186. https://doi.org/10.1002/mar.20596

Lee, S., \& Heere, B. (2018). Exploring the relative effectiveness of emotional, rational, and combination advertising appeals on sport consumer behavior. Sport Marketing Quarterly, 27(2).

Luna-Cortés, G. (2017). The Influence of symbolic consumption on experience value and the use of virtual social networks, Spanish Journal of Marketing, 21(1), 39-51. https://doi.org/10.1016/j.sjme.2016.12.005

Meyers-Levy, J., \& Malaviya, P. (1999). Consumers' processing of persuasive advertisements: An integrative framework of persuasion theories. Journal of Marketing, 63(4), 45-60. https://doi.org/10.1177/00222429990634s106

Mitchell, V. W., \& Lodhia, A. (2017). Understanding the metrosexual and spornosexual as a segment for retailers. International Journal of Retail \& Distribution Management, 45(4), 349-365. https://doi.org/10.1108/IJRDM-05-2016-0080

O'cass, A., \& McEwen, H. (2004). Exploring consumer status and conspicuous consumption. Journal of Consumer Behaviour, 4(1), 25-39. https://doi.org/10.1002/cb.155

Pan, H. H., \& Jamnia, M. (2015). Concept and phenomenon: A metrosexual perspective. Global Journal of Arts Humanities and Social Sciences, 3(5), 22-34.

Petty, R. E., Cacioppo, J. T., \& Schumann, D. (1983). Central and peripheral routes to advertising effectiveness: The moderating role of involvement. Journal of Consumer Research, 10(2), 135-146. https://doi.org/10.1086/208954

Petty, R. E., Fabrigar, L. R., \& Wegener, D. T. (2003). Emotional factors in attitudes and persuasion. In R. J. Davidson, K. R. Scherer, \& H. H. Goldsmith (Eds.), Handbook of Affective Sciences (pp. 772-752). Oxford University Press.

Reed, A. (2002). Social identity as a useful perspective for self-concept-based consumer research. Psychology \& Marketing, 19(3), 235-266. https://doi.org/10.1002/mar.10011

Rucker, D. D., \& Galinsky, A. D. (2009). Conspicuous consumption versus utilitarian ideals: How different levels of power shape consumer behavior. Journal of Experimental Social Psychology, 45(3), 549-555. https://doi.org/10.1016/j.jesp.2009.01.005

Ruiz, S., \& Sicilia, M. (2004). The impact of cognitive and/or affective processing styles on consumer response to advertising appeals. Journal of Business Research, 57(6), 657-664. https://doi.org/10.1016/S0148-2963(02)00309-0

Servidio, R. (2015). Images, affective evaluation and personality traits in tourist behaviour: An exploratory study with Italian postcards. Tourism Management Perspectives, 16, 237-246. https://doi.org/10.1016/j.tmp.2015.08.003

Silvera, D. H., \& Austad, B. (2003). Factors Predicting the Effectiveness of Celebrity Endorsement Advertisements. European Journal of Marketing, 38(11/12), 1509-1526. https://doi.org/10.1108/03090560410560218

Sirgy, M. J. (1982). Self-concept in consumer behavior: A critical review. Journal of Consumer Research, 9(3), 
287-300. https://doi.org/10.1086/208924

Supanvanij, J., \& Amine, L. S. (2000). Consumer perception of country-of-origin effect and brand effect. Latin American Business Review, 1(4), 47-60. https://doi.org/10.1300/J140v01n04_03

Stratton, G., \& Northcote, J. (2016). When totems beget clans: The brand symbol as the defining marker of brand communities. Journal of Consumer Culture, 16(2), 493-509. https://doi.org/10.1177/1469540514528194

Thiyagarajan, S., \& Shanthi, P. (2012). Vanity of Indians and the success of the cosmetic advertisements. New Media and Mass Communication, 6, 17-26. https://doi.org/10.7176/NMMC.vol617-26

Tseng, C. Y. (2012). Vision Imagery and Scent of Male Fragrance in Perfume Print Advertising. Unpublished master's thesis, National Taichung University of Science and Technology, Taichung City, Taiwan.

Tuna, S., \& Freitas, E. (2012). Gendered adverts: An analysis of female and male images in contemporary perfume ads. Comunicação e Sociedade, 21, 95-107. https://doi.org/10.17231/comsoc.21(2012).702

Vakratsas, D., \& Ambler, T. (1999). How advertising works: what do we really know?. The Journal of Marketing, 63(1), 26-43. https://doi.org/10.2307/1251999

Wang, J., Bao, J., Wang, C., \& Wu, L. (2017). The impact of different emotional appeals on the purchase intention for green products: The moderating effects of green involvement and Confucian cultures. Sustainable Cities and Society, 34, 32-42. https://doi.org/10.1016/j.scs.2017.06.001

Wattanasuwan, K. (2005). The self and symbolic consumption. Journal of American Academy of Business, 6(1), $179-184$

Wu, M. S. S., Chaney, I., Chen, C. H. S., Nguyen, B., \& Melewar, T. C. (2015). Luxury fashion brands: factors influencing young female consumers' luxury fashion purchasing in Taiwan. Qualitative Market Research: An International Journal, 18(3), 298-319. https://doi.org/10.1108/QMR-02-2014-0016

Yang, C. M. (2018). Effects of message strategy and need for cognition (NFC) on consumer attitudes: a case of corporate social responsibility (CSR) advertising. Open Journal of Business and Management, 6(3), 714-732. https://doi.org/10.4236/ojbm.2018.63055

Youn, S., \& Kim, H. (2018). Temporal duration and attribution process of cause-related marketing: Moderating roles of self-construal and product involvement. International Journal of Advertising, 37(2), 217-235. https://doi.org/10.1080/02650487.2016.1225332

Zaichkowsky, J. L. (1986). Conceptualizing involvement. Journal of Advertising, 15(2), 4-34. https://doi.org/10.1080/00913367.1986.10672999

Zaichkowsky, J. L. (1985). Measuring the involvement construct. Journal of Consumer Research, 12(3), $341-352$. https://doi.org/ 10.1086/208520

Zeng, X., \& Wang, S. (2016). A Study on the TV Commercials of Luxury Female Perfumes. Proceedings of the 2016 International Conference on Engineering Science and Management, 46-49. Atlantis Press. https://doi.org/10.2991/esm-16.2016.12

Zhang, H., Sun, J., Liu, F., \& Knight, G. J. (2014). Be rational or be emotional: Advertising appeals, service types and consumer responses. European Journal of Marketing, 48(11/12), 2105-2126. https://doi.org/10.1108/EJM-10-2012-0613 